Our Nature (2004) 2:45-46

\title{
Report of Molluscs from Chimdi lake (Birju Tal), Sunsari district, Eastern Nepal.
}

\author{
Ranjana Surana, B.R. Subba and K.P. Limbu \\ Tribhuvan University \\ Department of Zoology \\ Post Graduate Campus, Biratnagar, Nepal \\ E-mail:limbukp@yahoo.com
}

\begin{abstract}
Molluscs from Chimdi lake have been reported. Ten species of Gastropod representing seven families and four species of bivalves representing two families are described here.
\end{abstract}

Keywords: Molluscs, Chimdi lake, Sunsari

\section{Introduction}

Chimdi lake lies in $26^{\circ} 29^{\prime} 23.5^{\prime \prime} \mathrm{N}$ and $87^{\circ} 10^{\prime} 51.3^{\prime \prime} \mathrm{E}$ at an elevation of $70 \mathrm{~m}$.It falls in Chimdi VDC of Sunsari district, 12 kilometer far from Biratnagar. Up to five years ago, this natural lake was totally occupied by the local people and had made farmland. By the effort of local authorities and non-government organization, now it is being brought rehabilitation stage. The area is expanded up to 101.6-hectare land. Since last three years, its 17.85 hector land of eastside has filled with water and is rich in macrophytes that serve as a good habitat for the molluscs.

An attempt has been made to document molluscan species from Chimdi lake area. Reports of molluscs have been made from Nepal by Subba and Ghosh $(2000,2001)$ and Subba (2003).

\section{Materials and Methods}

The work was started from November 2003. Molluscs were collected eight months. The collected samples were identified with the help of standard books (Subba Rao 1989, Preston 1915). Some unidentified species were sent to the Zoological survey of India
(ZSI), Calcutta for identification.

\section{Results and Discussion}

Notable contributions have been made by Subba and Ghosh (2000,2001), Subba (2003) on the molluscan diversity in Nepal. In the present study, 14 species of molluscs belonging to nine families were collected and identified. Edible molluscs are considered parallel to the weed fishes here. Bellamya, Brotia, Pila, Lamellidens and Parreysia are some of the edible molluscan genera of this area. Sustainable utilization of molluscs is also essential because molluscs serve as food for many waterfowls inhabiting the lake area. Two species $P$. flavidens deltae(Benson )and $P$. (Radiatula) lima(Simpson) of this report are new to Nepal.

The list of Molluscs so far recorded from Chimdi lake is as follows:-

Phylum - Mollusca

Class - Gastropoda

Order - Mesogastropoda (Pectinibranchia)

(1) Family - Viviparidae

(i) Bellamya bengalensis f. typica (Lamarck, 1822)

(2) Family - Pilidae 
Ranjana Surana, B.R. Subba and K.P. Limbu / Our Nature (2004) 2:45-46

(ii) Pila globosa (Swainsen, 1822)

(3) Family - Thiaridae 1822)

(iii) Thiara (Tarebia) granifera (Lamarck,

(iv) Brotia costula (Rafinesque, 1833)

Order - Basommatophora

(4) Family - Lymnaeidae

(v) Lymnaea (Pseudosuccinea) acuminata

f. typica (Lamarck) 1822)

(vi)Lymnaea luteola f. typical (Lamarck,

(5) Family - Planorbidae 1834)

(vii) Indoplanorbis exutus (Deshayes, 1849)

(viii)Gyraulus convexiusculus (Hutton,

Order - Stylommatophora

(6) Family - Ariophantidae

(ix) Khasiella pansa

Order - Pulmonata

(7) Family - Stenogyridae

(x) Achatina fulica

Class - Bivalvia (Pelecypoda)

Order - Eulamellibranchiata

(8) Family - Unionidae 1819)

(xi) Lamellidens marginalis (Lamarck,

(9) Family - Amblemidae

(xii) Parreysia corrugata

(xiii)Parreysia flavidens deltae (Benson)

(xiv)Parreysia (Radiatula) lima (simpson)

\section{Acknowledgements}

The first author is thankful to Pro-public for financial support. Authors would like to extend their sincere thanks to Mr. Shaligram Adhikari, Mr. Ganesh Tamang, Mr. Ambika Dhakal of Tribhuvan University (Department of Zoology), Post Graduate Campus Biratnagar, who helped to carry out the present work up to this state. Authors are thankful to the Director, Z.S.I Calcutta for the identification and confirmation of molluscs. Bijaya Rajbanshi and Satya Narayan Choudhary are also thankful for their cooperation and selfless help during field visit.

\section{References}

Preston, H. B. 1915. The Fauna of British India including Ceylon and Burma. Mollusca (Freshwater Gastropoda and Pelecypoda). Taylor and Francis, London, pp.i-xi+ 244.

Subba, B. R. and T. K. Ghosh 2000. Some freshwater molluscs from eastern and central Nepal, J.Bomb. Nat.His.Soc.97 (3): 452-455.

Subba, B. R. and T. K. Ghosh 2001. Land molluscs from eastern and central Nepal. J. Bomb. Nat. Hist. Soc.97 (4): 58-61

Subba,B.R(2003): Molluscan checklist of Ghodaghodi Tal Area, Kailali Distict.Our Nature 1(1):1-2.

Subba Rao, N. V. 1989. Handbook of Freshwater Molluscs of India. Publ. Zoological Survey of India, Calcutta. 